\title{
Dimensional change of acrylic resin plate after the reinforcement of glass fibre
}

\author{
Dwiyanti Feriana Ratwita and Rinda Mahalistiyani \\ Department of Dental Material and Technology \\ Faculty of Dentistry Airlangga University \\ Surabaya - Indonesia
}

\begin{abstract}
The effect of fibre reinforcement of polymethyl methacrylate was investigated. Glass fibres have been studied as strengthening material added to polymethyl methacrylate. The purpose of this study was to evaluate dimensional change of acrylic resin plate after glass fibre reinforcement. As a research subject is an acrylic resin plate of $65 \times 10 \times 2.5 \mathrm{~mm}$ with the number of 32 samples were distributed randomly in 4 experimental groups. Each group consisted of 8 samples and control groups. Group 1: acrylic resin plate and 1 sheet glass fibre; group 2: acrylic resin plate and 2 sheet glass fibre; group 3: acrylic resin plate and 3 sheet glass fibre. Control group which was not given treatment. Dimensional change was measured by profile projector. The data was analyzed by One-Way ANOVA and LSD test showed that there was significant difference in dimensional change $(p<0.005)$. The conclusion suggested that dimensional change of the acrylic resin plates after glass fibre reinforcement minimally done 1 sheet glass fibre.
\end{abstract}

Correspondence: Dwiyanti Feriana Ratwita, c/o: Bagian Ilmu Material dan Teknologi Kedokteran Gigi, Fakultas Kedokteran Gigi Universitas Airlangga. Jln. Mayjend. Prof. Dr. Moestopo 47 Surabaya 60132, Indonesia.

\section{INTRODUCTION}

Acrylic resin especially polymethyl methacrylate (PMMA) is frequently used as denture base in dentistry field. The use of acrylic resin is due to the advantageous property such as fulfilling aesthetic requirement, either the color or the texture could be made similar to gingival so the aesthetic performance in oral cavity is good, the absorption is relatively low, the dimensional change is small. Easily repaired and processed when it is broken and the most important thing is relatively cheap. ${ }^{1,2,3}$

Despite the advantageous property there are some disadvantageous properties of acrylic resin denture base i.e. fragile against hard surface or fatigue due to repeated flexure of a load, ${ }^{4}$ being broken due to unequal chewing pressure, especially, if the pressure is stronger than flexural power of the dental material, so that, repeated broken of denture base would occur. ${ }^{5}$ The most fragile part of the acrylic resin denture base is the frenulum.

The acrylic resin dental material is continually developed in order to obtain better physical and mechanical property, one of the methods to make it better by adding strengthening material into acrylic resin material are: polymethyl fibre, composite glass carbon and aramid.,

In Indonesia, not all of strengthening acrylic resin base is available on the market. The use of glass fibre is based on beneficial consideration i.e. being able to increase physical and mechanical property of acrylic resin. ${ }^{6,7}$ One of widely used polymer materials in dentistry field is PMMA of crosslink type, due to the additional material: ethylenglyco methacrylate which can increase the mechanical strength of acrylic resin. 8
To overcome the shortcomings, a study has been performed on various types of glass fibre as strengthening material: PMMA. Giving glass fibre into acrylic resin functions as strengthening material is possible to be done since glass fibre can adhere to polymer matrix so that it might increase the strength of acrylic resin. ${ }^{8,9}$ The other factors which correlate with the strength are the quantity of glass fibre on polymer matrix and the adhesion of fibre. The effect of glass fibre adhesion on polymer is the important aspect due to the strong effect of the attachment. ${ }^{10}$ The accurate placement of glass fibre in acrylic resin is the most important requirement. There are two kinds of placement i.e. partial fibre reinforcement (PFR) which is placed on the weakest part and total fibre reinforcement (TFR) which is placed on the whole part. ${ }^{10}$ Filling glass fibre as strengthening material will increase the transverse strength of denture. ${ }^{11,12}$

Glass fibre which is used in the form of cloth and placed in the middle of the acrylic resin will perform the most effective strength to the load force of acrylic resin. Glass fibre as reinforcement should have longer size than the diameter size in adding the fibre into the polymer, the polymer would attach mechanically on the fibre and continue the polymerization process on the surrounding fibres. The polymer will distribute the load to the fibres which are the stronger component and also will protect the fibres from the moisturizing effect ${ }^{13}$ another study suggested that the use of 2 sheet glass fibre might increase the transverse strength, the quantity of the fibre in polymer matrix and the adhesion of fibre would really affect the adhesion strength. ${ }^{9,14}$ 
Dimensional stability of denture case during the processing period is the most important, because it would affect on the accuracy of denture in the oral cavity. The dimensional change of denture case would possibility occurred during the processing period and curing process which correlates with water absorption, this case is due to the excessive thickness so that the polymerization process would be hamped.

Dimensional change of acrylic resin is $<1 \%$, the frequently part in which the most dimensional change would occur is in the frontal area: $0.2-8.1 \%$ meanwhile in the lateral area is $0.2-9 \%$. Based on the above background, so it is necessary to perform the study on the effect of glass fibre reinforcement to dimensional change of acrylic resin plate. ${ }^{15}$ The purpose of this study was to know dimensional change of acrylic resin plate after glass fibre reinforcement. The benefit of this study is to stimulate innovation on acrylic resin with glass fibre inforcement to dimensional change.

\section{MATERIAL AND METHODS}

Research materials which were used in this study were: acrylic resin heat cured crosslink (Vertex-Dentimex), separator material (CMS, QC), hard gypsum, vaseline, aquadest, glass fibre of woven type (Yakasu, Japan). The tools which were used were: model master $($ size $65 \times 10 \times 2.5 \mathrm{~mm}),{ }^{16}$ cuvet, digital analytic (Vertling, Jerman), hydraulic press (Bego, Jerman), vacum mixer, profile projector (Nikon, Japan).

The process of making sample is hard gypsum with the ratio between the powder and aquadest: $50 \mathrm{~g}: 15 \mathrm{~mL}$ (according to manufacture recommendation ), mixed using vacuum mixer for 30 seconds, then gypsum dough put into the curvet placed on vibrator. Master model made of metal size $65 \times 10 \times 2.5 \mathrm{~mm}$ placed in the middle of cuvet on hard gypsum dough. Two specimen of master model was planted and arranged in parallel direction and made the gypsum hardening for about 15 minutes, after hardening the surface of gypsum was polished by vaseline. The antagonistic cuvet was planted and filled completely by hard gypsum was dough on the vibrator. After the gypsum was hardened then curvet was opened, the master model was taken out, finally the mould was obtained.
Next, heat cured acrylic resin was filled into the mould, the ratio between powder and acrylic resin liquid 4,6 $\mathrm{g}: 3$ $\mathrm{ml}$ (according to manufacture recommendation) mixed and stirred in porcelain pot, mould surface was dry. The sample was made by adding glass fibre with the following method: polymer and monomer of heat cured acrylic resin which had been mixed until it reached dough stage, then, divided into two: half was put into the mould on the upper part of curvet and the other half was put into the mould on the lower part of curvet, the next step, mould on the lower part of cuvet was added 1 sheet glass fibre (group 1). 2 sheet glass fibre (group 2) and 3 sheet (group 3). On the control group without being added glass fibre, finally cuvet was closed and pressed using hydraulic bench press, with pressure $2200 \mathrm{psi}$ or $50 \mathrm{~kg} / \mathrm{mm}^{2}$. The procedure was repeated three times and let them dry for 15 minutes. Curing process was done in cuvet with acrylic resin, through boiling process for 1 hour in the pot containing 3 liter water, temperature $100{ }^{\circ} \mathrm{C}$, until curing process was completed and it became cold then it was opened. Sample of acrylic was taken out and fined using abrasive paper no 1000 afterward, it was kept in the bottle glass and soaked into the water for $2 \times 24$ hour in order not to be dry.

In this study, the number of samples was 32 and every group consisted of 8 samples in 4 experimental groups. The test of dimensional change on acrylic resin plate was done using profile projector (Nikon), acrylic resin was placed on plate steel infront of the lens. The reflection of the acrylic resin could be seen on the screen. The number stated on the monitor would be noted and calculated using the equation. ${ }^{15}$ Dimensional change which studied was vertical and horizontal dimension.

$$
\text { Dimension change }=\mathrm{L}_{1}-\mathrm{L}_{0}
$$

Note: $\mathrm{L}_{0}=$ initial length $(\mathrm{mm})$

$\mathrm{L}_{1}=$ end length (mm)

\section{RESULT}

The mean result and standard deviation of the study on the effect of reinforcement of glass fibre toward

Table 1. The mean and standard deviation resulted from strengthening material of glass fibre toward dimensional change of acrylic plate (mm)

\begin{tabular}{ccccc}
\hline No. & Control & $\begin{array}{c}\text { Mean of length change and } \\
\text { standard deviation }\end{array}$ & $\begin{array}{c}\text { Mean of width change and } \\
\text { standard deviation }\end{array}$ & $\begin{array}{c}\text { Mean of thickness change and standard } \\
\text { deviation }\end{array}$ \\
\hline 1. & Group 1 & $1,757 \pm 0,066$ & $1,186 \pm 0,090$ & $0.390 \pm 0,042$ \\
2. & Group 2 & $1,829 \pm 0,084$ & $1,554 \pm 0,096$ & $0.516 \pm 0,094$ \\
3. & Group 3 & $2,276 \pm 0,097$ & $2,002 \pm 0,099$ & $0.563 \pm 0,040$ \\
4. & Control & $1,503 \pm 0,055$ & $0,791 \pm 0,063$ & $0.300 \pm 0,046$ \\
\hline
\end{tabular}

Note:

Group 1: Acrylic resin plate +1 sheet glass fibre; Group 2: Acrylic resin plate +2 sheet glass fibre; Group 3: Acrylic resin plate +3 sheet glass fibre; Control: Uncontrol group. 
dimensional change of acrylic resin plate would be shown on table 1.

The data on the effect of strengthening material of glass fibre toward dimensional change of acrylic plate was analyzed using One-Way ANOVA test. ANOVA test was preceded by homogeneity data test using Levene test. The result of homogeneity test found: length change $p=0.746(p>0.05)$, width change $p=0.103(p>0.05)$, this means all the data on length width thickness change of acrylic resin plate derivate from homogeneous source. The result of ANOVA test $\mathrm{p}=0.001(\mathrm{p}<0.05)$ means there is significant difference on length width, and thickness of acrylic resin plate. In order to know significant between treatment, followed by Least Significant Different (LSD) shows on table 2.

Table 2. LSD test, the effect of strengthening material of glass fibre toward length change of acrylic resin plate $(\mathrm{mm})$

\begin{tabular}{lcccc}
\hline & Control & Group 1 & Group 2 & Group 3 \\
\hline Control & - & $\mathrm{S}$ & $\mathrm{S}$ & $\mathrm{S}$ \\
Group 1 & - & - & $\mathrm{NS}$ & $\mathrm{S}$ \\
Group 2 & - & - & - & $\mathrm{S}$ \\
Group 3 & - & - & - & - \\
\hline
\end{tabular}

Note: S: Significant $(\mathrm{p}<0.05)$; NS: Non significant

Table show that in every control group there is significant difference $\mathrm{p}=0.01(\mathrm{p}<0.05)$, except on length change between group 1 compared with group 2 $\mathrm{p}=0.076(\mathrm{p}>0.05)$. Table 3 shows in every control there is significant difference $\mathrm{p}=0.01(\mathrm{p}<0.05)$. Table 4 shows in every control group there is significant difference $\mathrm{p}=0.01(\mathrm{p}<0.05)$, except the thickness change between group 1 compared with group 3 ( $p>0.05)$.

Tabel 3. LSD test, the effect of strengthening material of glass fibre to width change of acrylic resin plate (mm)

\begin{tabular}{lcccc}
\hline & Control & Group 1 & Group 2 & Group 3 \\
\hline Control & - & $\mathrm{S}$ & $\mathrm{S}$ & $\mathrm{S}$ \\
Group 1 & - & - & $\mathrm{S}$ & $\mathrm{S}$ \\
Group 2 & - & - & - & $\mathrm{S}$ \\
Group 3 & - & - & - & - \\
\hline
\end{tabular}

Note: S: Significant $(\mathrm{p}<0.05)$

Tabel 4. LSD test, the effect of strengthening material of glass fibre toward thickness change of acrylic resin plate $(\mathrm{mm})$

\begin{tabular}{lcccc}
\hline & Control & Group 1 & Group 2 & Group 3 \\
\hline Control & - & $\mathrm{S}$ & $\mathrm{S}$ & $\mathrm{S}$ \\
Group 1 & - & - & $\mathrm{S}$ & $\mathrm{NS}$ \\
Group 2 & - & - & - & $\mathrm{S}$ \\
Group 3 & - & - & - & - \\
\hline
\end{tabular}

Note: S: Significant $(\mathrm{p}<0.05)$; NS: Non Significant

\section{DISCUSSION}

Some of literary consideration which indicate the dimensional accuracy of acrylic resin plate are important to obtain accurate molding. In this study, a great number of variables are controlled in order to gain homogeneous samples, but some factors are completely beyond the capability such as: The placement of glass fibre in the middle of acrylic resulting of un similarity among one and the others, in which it might influence the outcome of the study. However the short coming has been minimalized.

Dimensional change closely related by the stability and the retention of removable denture therefore dimensional change would be correlated with comfort or discomfort of denture. ${ }^{17,18}$ Some factors induce dimensional changes are the between monomer and polymer, the type of acrylic resin, the curing process and storing factors. Furthermore, the monomer absorption of acrylic resin after curing process is also one of the causes of dimensional change of denture. ${ }^{15}$ The most dimensional change is caused by polymerization shrinkage of acrylic in strengthening material of glass fibre. The high ratio of the difference between monomer and polymer might cause higher dimensional change. ${ }^{13,19}$

The outcome of study suggest that the influence of strengthening material of glass fibre on the dimensional change of acrylic resin plate found the highest mean of change: $2.276 \mathrm{~mm}$, the width change: $2.002 \mathrm{~mm}$ and the thickness change: $0.563 \mathrm{~mm}$, occurring in the addition of 3 sheet glass fibre. This case might be due to the use of excessive glass fibre which could contribute the biggest absorption of monomer during curing process. The more glass fibres are used resulting higher dimensional change. $^{14}$

It is advisable to be well considered the use of strengthening material of glass fibre because glass fibres have monomer absorption property. Therefore, fluid absorption of acrylic resin is an important phenomenon to be considered due to the direct correlation to dimensional change. $^{20}$

Different curing process also contributes different dimensional change, acrylic of heat-cured type has worse dimensional accuracy than acrylic of cold-cured type because acrylic of cold-cured type has lower tensile surface, smaller dimensional change and better adaptation property, linear shrinkage value or shrinkage of acrylic cold-cured type is about $0.01-0.43 \%$, meanwhile shrinkage value of acrylic heat-cured type is $0.5 \% .^{21}$

One-Way ANOVA test, significant difference was found with $p=0.001(p<0.05)$ for the whole change of least, width and thickness. LSD was done in order to understand the effect of the difference, the result showed significant difference with $\mathrm{p}=0.001(\mathrm{p}<0.005)$ the significant change of length, width and thickness found in acrylic resin plate added by 1 sheet glass fibre with $\mathrm{p}=0.001(\mathrm{p}<0.005)$, the difference is due to the thickness of glass fibre which would affect the thickness of acrylic plate. The plate was due to the fibre tensility which is 
important property to strengthen fragile material such as: acrylic resin, therefore, strong adhesion of fibre attached to polymer is an essential factor to obtain the strength of acrylic resin. Proper adhesion could make better fluid absorption of acrylic resin polymer into the glass fibre so it would affect the dimensional change. ${ }^{13}$

The use of glass fibre as ideal strengthening material should have higher length comparing to the diameter. The in for cement of glass fibre into polymer, the polymer would mechanically attach to the glass fibre and, further, polymerization would continue at the surrounding part of glass fibre. Polymer would distribute the load into the fibre in a stronger component and also protect the acrylic resin from the moisture so the process might minimalize the dimensional change. ${ }^{9}$

In this study, it could be concluded that acrylic resin shows minimal dimensional change after reinforcement of 1 sheet of glass fibre.

\section{REFERENCES}

1. Combe EC. Notes on dental materials. $6^{\text {th }}$ ed. Edinburg, London, Melbourne, New York: Churchill Livingstone; 1992. p. 79-120.

2. Craig RG. Restorative dental material. $11^{\text {th }}$ ed. St Louis Missouri: Mosby Company; 2002. p. 655-8.

3. Taner B, Dogan A, Tincer T, Akinay AE. A study on impact and tensile strength of acrylic resin filled with short ultra-high molecular weight polyethylene fihers. J Oral Science 1999; 41:15-8.

4. Billmeyer FW. Textbook of polymer science. $3^{\text {rd }}$ ed. New York, Singapore: A Wiley Inter Science Pub, John Wiley \& Sons; 1984. p. 11-6.

5. Mitchell L, Mitchell DA. Oxford handbook of clinical dentistry. $3^{\text {rd }}$ ed. Oxford: Oxford University Press; 1999. p. 369, 700.

6. Vallitu PK. Glass fibre reinforcement in repaired acrylic resin removable denture preliminary results of clinical study. Quintessence Int 1997; 28:39-44.
7. Vallitu PK. Curing of silane coupling agent and its effect on the transverse strength of autopolymerizing polymethylmethacrylate glass fibre composite. J Oral Rehabil 1997; 24:124-30.

8. Vallitu PK, Lassila VP, Lappalaine RM. Acrylic resin-fibre composite. Part I. The effect of fibre concentration on fracture resistance. J Prosthet Dent 1994; 71:607-12.

9. Vallitu PK. Acrylic resin fibre composite. Part II. The effect of polymerization shrinkage of polymethylmethacrylate applied to fibre roving on transverse strength. J Prosthet Dent 1994; 71:613-7.

10. Vallitu PK. Flexural properties of acrylic resin polymers reinforced with undirectional and woven glass fibre. J Prosthet Dent 1999; $8: 318-25$.

11. Dixon DL, Fincher M., Breeding LC. Mechanical properties of light polymerizing provisional restorative material with and without reinforcement fibres. J Prosthet Dent 1995; 73:510-4.

12. Dixon DL, Fincher M, Breeding LC. The transverse strength of three denture base resins reinforced with polyethylene fibres. J Prosthet Dent 1995; 67:417-9.

13. Vallitu PK. Dimensional accuracy and stability of polymethylmethacrylate reinforced with metal wire or with continuous glass fibre. J Prosthet Dent 1996; 75:617-21.

14. Vallitu PK, Lassila UP. Reinforcement of acrylic resin denture base material with metal or fibre strengthenes. J Oral Rehabil 1992; 19:225-30.

15. Craig RG, O'Brien W, Powers JM. Dental materials properties and manipulation. $4^{\text {th }}$ ed. St Louis, Washington DC, Toronto: The CV Mosby Company; 2004. p. 264-80.

16. American Dental Association, ADA spesifikasi no. 12. Revised American National standard/ American Dental Association Specification. Denture base polymers. Chicago: American Dent Association 1975; 203-8.

17. Vallitu PK. A review of fibre-reinforced denture base resins. J Prosthet Dent 1996; 5:270-6.

18. Stipho HD. Repair of acrylic resin denture base reinforced with glass fibre. J Prosthet Dent 1998; 546-50.

19. Vallitu PK, Ruyter IE, Ekstrand K. Effect of water storage on the flexural properties of E-glass and silica fibre acrylic resin composite. Int J Prosthodont 1998; 11:340-50.

20. Reitz PV, Sanders JL, Levin B. The curing acrylic resins by microwave energy, physical properties. Quintessence International $1985 ; 8: 547-51$.

21. Salim S. Pengaruh humiditas dan lama penyimpanan serta cara kuring terhadap sifat fisik, kimia dan mekanik resin akrilik basis gigi tiruan. Dissertation. Surabaya: Universitas Airlangga; 1995. p. 5-45. 